\title{
理学療法施行患者の血圧における 訓練室初日効果の検討
}

\author{
First Day Hypertension in the Physical Therapy Exercise Room
}

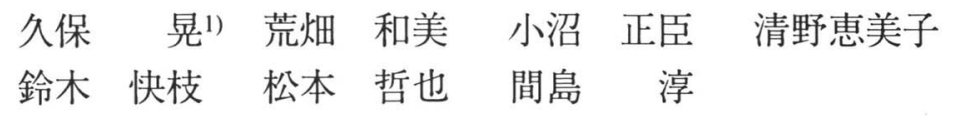

AKIRA KUBO, RPT ${ }^{1)}$, KZUMi ARAHATA, RPT, MASAOMI ONUMA, RPT, EMIKo SEINO, RPT, Yoshie SUZUKI, RPT, TETSUya MATSUMOTO, RPT, JUn MAJIMA, RPT

')Department of Physical Therapy, Tokyo Metropolitan Geriatric Hospital: 35-2 Itabashi-ku, Sakae-cho, Tokyo, 173 Japan. TEL +81 3-3964-1141.

J. Exerc. Physiol. 9(2): 91-95, 1994. Submitted April 22, 1994. Accepted May 10, 1994.

\begin{abstract}
We examined the change in blood pressure (BP) from first to fifth day in the physical therapy exercise room. BP was measured in 120 subjects aged $76.6 \pm 8.6$ years. Their systolic BP in first day was significantly higher than the other day $(\mathrm{p}<0.01)$. If an increment in systolic $\mathrm{BP}$ more than $10 \mathrm{mmHg}$ was defined as positive for first day hypertension, they were observed in $39.2 \%$. And subjects were divided into two groups, consisting of patients with and without former experience of physical therapy. The BP in patients with experience was stable during five days. In conclusion, we suggest that the first day hypertension is due to the mental stress of physical therapy exercise.
\end{abstract}

Key words: blood pressure, first day hypertension, experience of physical therapy

要旨 訓練室で理学療法を実施した 120 例（76.6 8 .6歳）を対象として訓練室初日から 5 日目までの血圧を 測定した。訓練室初日の収縮期血圧は有意に高く, 訓練室初日と 2 日目の収縮期血圧較差の $10 \mathrm{mmHg}$ 以上を 初日高血圧陽性とするとその頻度は, 全体の 47 例 (39.2\%) であった。過去の訓練経験の有無で分類すると, 有り群の血圧は安定していたが, 無し群では初日の血圧が有意に高く, 過去の訓練経験の有無が血圧に関与 し，一種の精神的なストレスに対する昇圧反応と考えられた。 キーワード：血圧，訓練室初日効果，訓練経験

1)東京都老人医療センター 理学療法科：東京都板橋区栄町35-2 ( ₹ 173) TEL 03-3964-1141. 


\section{I 緒 言}

訓練室での理学療法 (以下 $\mathrm{P} \mathrm{T}$ ) 初日には, 血 圧が上昇し, 患者本来の血圧を必ずしも反映して いないことを臨床上しばしば経験する。高血圧症 患者の血圧の変動に関して, 医師が血圧を測定す る際に一過性に血圧が上昇する現象を白衣高血圧 症あるいは白衣効果と呼び注目を集めている1-4)。 $\mathrm{P}$ Tを実施する際にも訓練室での P T 初日に血圧が 上昇する現象 (以下訓練室初日効果) が存在する のではないだろうか。しかし，P Tにおけるこの ような現象の原因や頻度などについては明らかに されていない。

そこで我々は, 老人医療センターに入院し, P Tを処方された患者において訓練室初日から5 日 目までの訓練室における血圧を測定し，その変化 から訓練室初日効果の頻度や過去の P T の経験の 有無が訓練室初日の血圧に与える影響を検討し た。

\section{II 対象と方法}

東京都老人医療センターP T 科に訓練を処方 された 120 例の入院患者に対し, 訓練室での訓練 開始日より5 日目まで間, 訓練室入室後で P T 開 始前の血圧を測定した。平均年齢は $76.6 \pm 8.6$ 歳 (SD) (57 93歳) で男 41 例女 79 例（表 1 ）であ る。年齢の構成は50歳代 7 例, 60 歳代 19 例, 70 歳代 36 例, 80 歳代 56 例, 90 歳代 2 例である。主 たる疾患の内訳は, 脳血管障害および神経難病 81 例, 整形外科 25 例, 循環器 3 例, 外科 3 例, その他 8 例である。

血圧計は水銀血圧計とタイコス型血圧計の 2 種 類を用いた。測定は 2 名の男性 P Tが担当し, 各 患者に対し，同一の $\mathrm{P} \mathrm{T}$ が，同一の体位，同側の 上腕で測定し，同種類の血圧計を使用して 5 日間 測定を行った。そして，医師が血圧を測定する際 に一過性に血圧が上昇する白衣効果の影響を考慮 し, 訓練室での P T を実施する以前に病棟にてオ リエンテーションを行い, 測定者による血圧変動

表 1 対象者の背景因子

\begin{tabular}{|c|c|c|c|}
\hline & 男（年齢） & 女 (年齢) & 合計（年齢） \\
\hline \multicolumn{4}{|l|}{ 疾患名 } \\
\hline 中枢神経 & $34(74.2 \pm 9.6)$ & $47(76.6 \pm 7.9)$ & $81 \quad(75.6 \pm 8.8)$ \\
\hline 整形外科 & $2(78.5 \pm 7.5)$ & $23(77.8 \pm 8.6)$ & $25(77.9 \pm 8.7)$ \\
\hline 外 科 & $1(77)$ & $2(81.0 \pm 5.7)$ & $3(79.7 \pm 4.6)$ \\
\hline 循環器 & $1(73)$ & $2(76.5 \pm 10.6)$ & $3(75.3 \pm 7.8)$ \\
\hline その他 & $3(84.0 \pm 2.2)$ & $5(80.2 \pm 4.9)$ & $8(81.6 \pm 4.8)$ \\
\hline \multicolumn{4}{|l|}{ 年 代 } \\
\hline 50 代 & 5 & 2 & 7 \\
\hline 60 代 & 6 & 13 & 19 \\
\hline 70 代 & 10 & 26 & 36 \\
\hline 80 代 & 20 & 36 & 56 \\
\hline 90 代 & 0 & 2 & 2 \\
\hline \multicolumn{4}{|l|}{ 高血圧症 } \\
\hline あり & $25(75.6 \pm 8.4)$ & $45(77.3 \pm 8.1)$ & $70(76.7 \pm 8.3)$ \\
\hline な し & $16(73.8 \pm 10.4)$ & $34(76.8 \pm 7.9)$ & $50 \quad(77.9 \pm 9.0)$ \\
\hline \multicolumn{4}{|l|}{ 理学療法経験 } \\
\hline あり & $23(74.0 \pm 10.6)$ & $33(78.7 \pm 7.1)$ & $56(76.8 \pm 9.1)$ \\
\hline な し & $18(76.7 \pm 7.1)$ & $46(76.2 \pm 8.4)$ & $64(76.4 \pm 8.2)$ \\
\hline 合 計 & $41 \quad(75.2 \pm 9.4)$ & $79(77.3 \pm 8.0)$ & $120(76.6 \pm 8.6)$ \\
\hline
\end{tabular}


を起こさないよう配慮した。

120 例の中には降圧剤服用中の高血圧症患者が 含まれていたが，血圧が訓練の支障にはならない との主治医, リハビリテーション医両者の判断で $\mathrm{P} \mathrm{T}$ への処方がなされた。そこで高血圧症のある 70 例とない 50 例で訓練室初日から 5 日目までの 間の血圧に違いがあるかの検討をした。また，過 去の当センターおよび他院での P T 訓練経験のあ る 56 例と,ない 64 例により同様の検討を加え た。

統計は日間の比較には対応のある $\mathrm{t}$ 検定，群間 比較には平均値の差の検定, 頻度分析には $x^{2}$ 検定 を用い，5\%未満を有意差ありとした。

\section{III 結 果}

訓練室初日から 5 日目までの間の血圧 (収縮期 /拡張期) (表 2) は, 初日から順に $134 \pm 20 / 73$ $\pm 13 \mathrm{mmHg}, 128 \pm 19 / 72 \pm 13 \mathrm{mmHg}, 128 \pm 18$ / $72 \pm 12 \mathrm{mmHg}, 126 \pm 19 / 72 \pm 12 \mathrm{mmHg}, 128 \pm 21 /$ $71 \pm 11 \mathrm{mmHg}$ となった。拡張期血圧は訓練室初 日から 5 日間いずれも有意な変化を示さなかっ た。しかし収縮期血圧は初日が高く，2 日目は低 下し, 以後ほほ同様の収縮期血圧となった。初日 の収縮期血圧は 2 日目以降のどの日よりも有意に
高い値を示した $(p<0.01)$ 。

高血圧群の訓練室初日から 2 日目までの間の血

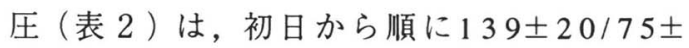
$14 \mathrm{mmHg}, 132 \pm 21 / 73 \pm 15 \mathrm{mmHg}, 131 \pm 19 / 73$ $\pm 12 \mathrm{mmHg}, 131 \pm 17 / 72 \pm 12 \mathrm{mmHg}, 133 \pm 21 /$ $73 \pm 11 \mathrm{mmHg}$ となった。非高血圧群の訓練室初日 から 5 日目までの間の血圧は, 初日から順に 127 $\pm 17 / 71 \pm 11 \mathrm{mmHg}, 122 \pm 16 / 71 \pm 10 \mathrm{mmHg}$, $123 \pm 15 / 70 \pm 12 \mathrm{mmHg}, 120 \pm 20 / 69 \pm 13 \mathrm{mmHg}$, $120 \pm 19 / 69 \pm 11 \mathrm{mmHg}$ となった。両群ともに拡張 期血圧は 5 日間いずれも有意な変化を示さなかっ た。しかし, 収縮期血圧は初日が 2 日目以降のど の日よりも有意に高い值を示した。また高血圧群 と非高血圧群の収縮期血圧の間には訓練室初日か ら 5 日目のいずれの日も有意な差が認められた。

過去に P T 訓練経験有り群の訓練室初日から 5 日間の血圧 (表 2 ) は, 初日から順に $132 \pm 19$ / $73 \pm 13 \mathrm{mmHg}, 131 \pm 20 / 73 \pm 14 \mathrm{mmHg}, 129 \pm 19$ / $74 \pm 12 \mathrm{mmHg}, 128 \pm 18 / 71 \pm 14 \mathrm{mmHg}, 131 \pm 24$ / $73 \pm 11 \mathrm{mmHg}$ となり, 収縮期, 拡張期とも 5 日間 有意な変化を示さなかった。一方, 過去に P T 訓 練経験無し群の訓練室初日から 5 日間の血圧は,

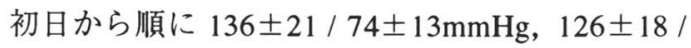
$72 \pm 13 \mathrm{mmHg}, 127 \pm 17 / 70 \pm 12 \mathrm{mmHg}, 125 \pm 20$ / $70 \pm 10 \mathrm{mmHg}, 125 \pm 17 / 70 \pm 11 \mathrm{mmHg}$ となった。

表 2 訓練室初日から 5 日目までの間の血圧の推移

\begin{tabular}{crrrrr}
\hline & 初 日 & 2 日目 & 3 日目 & 4 日目 & 5 日目 \\
\hline 全 体 $(\mathrm{n}=120)$ & & & & & \\
収縮期血圧 $(\mathrm{mmHg})$ & $134 \pm 20$ & $128 \pm 19$ & $128 \pm 18$ & $126 \pm 19$ & $128 \pm 21$ \\
拡張期血圧 $(\mathrm{mmHg})$ & $73 \pm 13$ & $72 \pm 13$ & $72 \pm 12$ & $72 \pm 12$ & $71 \pm 11$ \\
高血圧症あり $(\mathrm{n}=70)$ & & & & & \\
収縮期血圧 $(\mathrm{mmHg})$ & $139 \pm 20$ & $132 \pm 21$ & $131 \pm 19$ & $131 \pm 17$ & $133 \pm 21$ \\
拡張期血圧 $(\mathrm{mmHg})$ & $75 \pm 14$ & $73 \pm 15$ & $73 \pm 12$ & $72 \pm 12$ & $73 \pm 11$ \\
高血圧症なし $(\mathrm{n}=50)$ & & & & & \\
収縮期血圧 $(\mathrm{mmHg})$ & $127 \pm 17$ & $122 \pm 16$ & $123 \pm 15$ & $120 \pm 20$ & $120 \pm 19$ \\
拡張期血圧 $(\mathrm{mmHg})$ & $71 \pm 11$ & $71 \pm 10$ & $70 \pm 12$ & $69 \pm 13$ & $69 \pm 11$ \\
訓練経験あり $(\mathrm{n}=56)$ & & & & & \\
収縮期血圧 $(\mathrm{mmHg})$ & $132 \pm 19$ & $131 \pm 20$ & $129 \pm 19$ & $128 \pm 18$ & $131 \pm 24$ \\
拡張期血圧 $(\mathrm{mmHg})$ & $73 \pm 13$ & $73 \pm 14$ & $74 \pm 12$ & $71 \pm 14$ & $73 \pm 11$ \\
訓練経験なし $(\mathrm{n}=64)$ & & & & & \\
収縮期血圧 $(\mathrm{mmHg})$ & $136 \pm 21$ & $126 \pm 18$ & $127 \pm 17$ & $125 \pm 20$ & $125 \pm 17$ \\
拡張期血圧 $(\mathrm{mmHg})$ & $74 \pm 13$ & $72 \pm 13$ & $70 \pm 12$ & $70 \pm 10$ & $70 \pm 11$ \\
\hline
\end{tabular}


収縮期, 拡張期とも初日の血圧が高く, 2 日目以 降は低下した。統計的には初日の収縮期血圧は2 日目以降のどの日よりも有意に高く $(\mathrm{p}<0.01)$, 拡 張期では初日と 3,4 および 5 日目との間に有意 差が認められた $(\mathrm{p}<0.01)$ 。

訓練室初日と 2 日目の収縮期血圧較差別にその 頻度（表 3 ）をみると，0〜9 $\mathrm{mmHg}$ 上昇した例は 33 例 $(27.5 \%), 10 \sim 19 \mathrm{mmHg}$ の上昇は21例（17.5 $\%), 20 \mathrm{mmHg}$ 以上上昇した例は 26 例 $(21.7 \%)$ に認められた。一方, 2 日目に収縮期血圧が上昇 した例も 40 例 $(33.3 \%)$ に認められた。訓練室初 日と 22 日目の収縮期血圧較差の $10 \mathrm{mmHg}$ 以上を 訓練室初日効果陽性とすると訓練室初日効果陽性 者は, 全体の 47 例 (39.2\%) であった。

高血圧症の有無により訓練室初日効果陽性者
の頻度（表 4 ）をみると高血圧症群では 33 例 (47.1\%), 非高血圧症群では 14 例 $(28.0 \%)$ とな り, 高血圧症と訓練室初日効果の間に有意な関連 が認められた $(\mathrm{p}<0.05)$ 。また, 過去の P T 経験の 有無により訓練室初日効果陽性者の頻度（表 4) をみると P T 経験有り群では17例 (30.4\%) に対 し, P T 経験無し群では 30 例 $(46.9 \%)$ と高率に なったが有意差は認められなかった $(\mathrm{p}<0.10)$ 。

年代毎の初日効果陽性率 (表 5 ) では 50 歳代 で $14.3 \%, 60$ 歳代で $31.6 \%, 70$ 歳代で $41.7 \%, 80$ 歳代で $44.6 \%$ と加齢とともに頻度が増加する傾向 を示した。

表 3 訓練室初日と 2 日目の収縮期血圧の較差別頻度

\begin{tabular}{rrrrrr}
\hline & & \multicolumn{2}{c}{ 高血圧症 } & \multicolumn{2}{c}{ 理学療法経験 } \\
& 合 計 & あり & なし & あり & なし \\
\hline $20 \mathrm{mmHg} \uparrow$ & $26(21.7 \%)$ & $18(25.7 \%)$ & $8(16.0 \%)$ & $8(14.3 \%)$ & $18(28.1 \%)$ \\
$10 \sim 19 \mathrm{mmHg}$ & $21(17.5 \%)$ & $15(21.4 \%)$ & $6(12.0 \%)$ & $9(16.1 \%)$ & $12(18.8 \%)$ \\
$0 \sim 9 \mathrm{mmHg}$ & $33(27.5 \%)$ & $16(22.9 \%)$ & $17(34.0 \%)$ & $15(26.8 \%)$ & $18(28.1 \%)$ \\
$-10 \sim-1 \mathrm{mmHg}$ & $25(20.8 \%)$ & $10(14.3 \%)$ & $15(30.0 \%)$ & $14(25.0 \%)$ & $11(17.2 \%)$ \\
$-20 \sim-11 \mathrm{mmHg}$ & $9(7.5 \%)$ & $7(10.0 \%)$ & $2(4.0 \%)$ & $5(8.9 \%)$ & $4(6.3 \%)$ \\
$-21 \mathrm{mmHg} \downarrow$ & $6(5.0 \%)$ & $4(5.7 \%)$ & $2(4.0 \%)$ & $5(8.9 \%)$ & $1(1.6 \%)$ \\
\hline & 120 & 70 & 50 & 56 & 64 \\
\hline
\end{tabular}

表 4 訓練室初日効果陽性率

\begin{tabular}{|c|c|c|c|c|c|}
\hline & \multirow[b]{2}{*}{ 合 計 } & \multicolumn{2}{|c|}{ 高血圧症 } & \multicolumn{2}{|c|}{ 理学療法経験 } \\
\hline & & あり & なし & あり & なし \\
\hline \multicolumn{6}{|c|}{ 訓練室初日効果 } \\
\hline 陽 性 & $47(39.2 \%)$ & $33(47.1 \%)$ & $14(28.0 \%)$ & $17(30.4 \%)$ & $30(46.9 \%)$ \\
\hline 陰 性 & $73(60.8 \%)$ & $37(52.9 \%)$ & $36(72.0 \%)$ & $39(69.6 \%)$ & $34(53.1 \%)$ \\
\hline & 120 & 70 & 50 & 56 & 64 \\
\hline
\end{tabular}

表 5 年代毎の訓練室初日効果陽性率

\begin{tabular}{cccccccc}
\hline 初日効果 & 50 歳代 & 60 歳代 & 70 歳代 & 80 歳代 & 90歳代 & 合計 \\
\hline 陽 性 & $1(14.3 \%)$ & $6(31.6 \%)$ & $15(41.7 \%)$ & $25(44.6 \%)$ & 0 & $(0 \%)$ & $47(39.2 \%)$ \\
陰 性 & $6(85.7 \%)$ & $13(68.4 \%)$ & $21(58.3 \%)$ & $31(55.4 \%)$ & $2(100 \%)$ & $73(60.8 \%)$ \\
\hline & 7 & 19 & 36 & 56 & 2 & 120 \\
\hline
\end{tabular}




\section{IV 考 察}

従来からのリスク管理としては, 土肥や Andersonの基準があげられる。しかし, 老年者で は虚血性心疾患などを合併することが多く, 個々 の状態を考慮した対応がせまられる。小池ら5はリ 八科入院患者 150 例を対象に入院時検査として記 録した安静時の心電図を分析し，約 $40 \%$ に異常を 認め, 脳血管障害がその内の約 $70 \%$ と多く, 年齢 では 50 歳以上で出現率が増加したとしている。


所見を検討し, 心電図異常の出現頻度は 78.4\%で 加齢とともに出現率が増加し, 運動療法を施行す る際には心電図所見を確認する必要があると報告 している。

今回, 訓練室初日に患者本来の血圧より上昇す る現象がみられた。P T 経験の有無による検討 で, 経験のある群は 5 日間変化がなく, 経験の無 い群では初日の血圧が有意に高く, 2 日目より安 定するため,この現象の一因には過去の経験の関 与が示唆され, 一種の精神的なストレスに対する 昇圧反応と考えられる。臨床上, 虚血性心疾患を 合併している患者や脳出血の急性期などでは血圧 の管理が重要で, 血圧の上昇は再発に結びつく可 能性がある。初日には血圧が上昇することを考慮 したプログラムを立案する必要がある。

高血圧群 70 例の収縮期血圧は 130 $140 \mathrm{mmHg}$ であるのに対し, 非高血圧群 50 例の収縮期血圧 は 120〜130 mmHgで有意な差が認められた（表 2 )。しかし, 高血圧群は, 鈴木らフが報告した高 齢者における高血圧診断の基準值 $150 \mathrm{mmHg}$ 以下
で調整されていた。高血圧症と訓練室初日効果の 間に有意な関連が認められ $(\mathrm{p}<0.05)($ 表 4$)$, 高血 圧症の有無が訓練室初日効果の出現に影響をおよ ほしていることが示唆された。

また, 訓練室初日効果陽性者は, 全体の 47 例 (39.2\%) で, 加齢とともに頻度が増加する傾向 を示した (表 5 )。老年者では頚動脈や心肺圧受容 機能が減弱するため, 血圧変動に対する調節機能 が減弱することや大血管の弾性が消失している1)と され，加齢による血圧調節機構の減少と関連があ ると推察できる。一方，2日目に収縮期血圧が上 昇した例が 40 例 $(33.3 \%)$ に認められ, 個人差が 大きいことも示された。

\section{引用文献}

1) 桑島 膂: 24時間血圧変動. 心蔵, 25(5): 491-502, 1993.

2) 桑島 巌：老年者の白衣高血圧. 日本医事新報, (3611): 29-31, 1993.

3) 肥塚昌子.他：老年者における白衣効果の検討. 日老 医誌, 29(12): 912-917, 1992.

4) Pickering $T$, et al.: How common is white coat hypertension? JAMA, 259: 225-228, 1988.

5) 小池純子·他：心合併症. 総合リ八, 13(4):299-304, 1985.

6) 岩月宏泰·他：慢性期脳卒中患者の心電図異常につ いての一考察. 運動生理, 7(4): 215-220, 1992.

7) 鈴木康子·他：血圧日内変動におよぼす性, 加齢の影 響. 日老医誌, 30(9): 778-786, 1993. 